\title{
Fuel consumption comparison of two forwarders in lowland forests of pedunculate oak
}

\author{
Zdravko Pandur, \\ Marijan Šušnjar, \\ Marin Bačić, \\ Andreja Duka, \\ Kruno Lepoglavec, \\ Hrvoje Nevečerel
}

Fuel consumption of forest machinery and vehicles depends mainly on terrain conditions, working methods, drivers' skills, engine load under working conditions, engine speed, type and technical characteristics of the machine. In timber harvesting operations, fuel consumption is significant for both, economic (costs), and environmental issues (80-95\% of exhaust emissions and soot particles are associated with fuel consumption). The objective of this study was to compare fuel consumption in two different forwarders and to analyse two different measuring devices for fuel consumption. Fuel consumption was measured on a 6-wheeled Valmet 840.2 forwarder and an 8-wheeled Valmet 860.4 during roundwood and energy wood extraction in winter period. A differential fuel flow meter and a fuel measuring probe were used for measuring fuel consumption as well as a Fleet Management System (FMS) for transmitting measured data. Fuel consumption was expressed in six different ways depending on the stage of the working cycle, time, travelled distance, load volume and load mass. Finally, both the advantages and disadvantages of the used fuel measuring devices were gained. The results indicated higher fuel consumption of the smaller Valmet $\mathbf{8 4 0 . 2}$ forwarder due to lower soil bearing capacity and longer extraction distances. For both forwarders, higher fuel consumption (expressed in $\mathrm{t}^{-1} \mathrm{~km}^{-1}$ ) was observed while extracting energy wood due to its lower overall mass.

Keywords: Forwarder, Fuel Measuring, Timber Extraction, Load, Roundwood, Energy Wood

al. 2003, Manner et al. 2016).

The rational organisation of timber extraction consists of a series of factors that can affect the reduction of fuel consumption thus affecting the other costs of timber harvesting operations. Main factors influencing the reduction of fuel consumption are: (i) the selection of a vehicle, which is based on its technical characteristics and working conditions in the stand; (ii) the regular maintenance of the vehicle; (iii) the application of the appropriate technology with a good organisation of work, a motivation of the driver and his/her professional training.

Fuel consumption of machinery is often expressed as energy consumption per unit

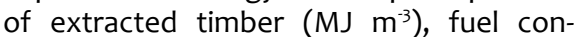
sumption per unit of extracted timber (I $\left.\mathrm{m}^{-3}\right)$ or per unit of time $\left(\mathrm{I} \mathrm{h}^{-1}\right)$. However, as the fuel consumption of timber extraction is directly dependent on the extraction distance, the most accurate way of expressing fuel consumption is per mass of extracted timber along with the extraction distance $\left(\mathrm{I} \mathrm{t}^{-1} \mathrm{~km}^{-1}\right)$ in both long-distance truck transportation or short-distance timber transportation from the stand to the landing site.

The simplest way to measure fuel consumption of machinery and vehicles is the volumetric method of refilling the tank with fuel at the end of the working operations or at the end of the working day. The filling up of the tank is carried out by using a measuring gauge or by using a measuring gun for accurate measurements (Sever et al. 1989).

Martinić et al. (1992) measured the fuel consumption of a tractor assembly by a Ivasim rotary gauge and concluded, that the fuel consumption is the highest during loading of logs and driving loaded vehicle, while the lowest fuel consumption was during unloading of logs and driving empty.

Nordfjell et al. (2003) stated that fuel consumption is traditionally measured by flow meters (Rebula 1989, Sever \& Horvat 1989, Potočnik 1989) while new technologies, especially those based on CAN (Controller Area Network) technique, enable cheaper and easier measurements (Rieppo \& Orn 2003). Lijewski et al. (2017) determined fuel consumption with the carbon balance method according to the procedure adopted by EPA, and this method is commonly accepted worldwide as the most accurate method for determining fuel consumption. In this method, the fuel consumption was calculated based on the emission of $\mathrm{CO}_{2}$. Manner et al. (2016) explored data collected and presented by John Deere ${ }^{T M}$ forwarders' conventional onboard computers (TimberLink ${ }^{\otimes}$ ). Standard TimberLink data were found to be intuitively logical; results were consistent with the current literature and gathering of high-resolution fuel con- 
sumption data on an annual basis was possible. However, elucidating main and interactive effects of variables and operator behaviour on fuel and time consumptions is challenging, and requires more detailed information regarding loads (e.g., volumes and number of assortments) as well as stand conditions (e.g., gross harvesting density and terrain conditions).

Nordfjell et al. (2003) estimated the fuel consumption of the unloaded forwarder in the range of 0.23 to 0.38 litres per 100 meters, while the fuel consumption of loaded forwarder was $10 \%$ higher in comparison with the unloaded one. Authors stated that the average fuel consumption of the forwarder is $13.3 \mathrm{I} \mathrm{h}^{-1}$ when working in the final felling, or $10.5 \mathrm{I} \mathrm{h}^{-1}$ in the thinning. Holzleitner et al. (2010) presented the results of 18 forwarders ( 6 models) for the period from 2004 to 2008 in the Austrian state forests where the average fuel consumption was 11.1 $\mathrm{I} \mathrm{h}^{-1}$. Rieppo \& Orn (2003) stated that average fuel consumption was $10.5 \mathrm{I} \mathrm{h}^{-1}$, while Nordfjell et al. (2003) reported that $61-62 \%$ of the fuel is consumed during loading of timber and driving of a loaded forwarder. The results of both papers were based on the average values of a large number of forwarders where detailed analyses regarding the influence of ground conditions and fuel system on fuel consumption were neglected (Suvinen 2006). Đuka et al. (2017) gave data on the calculated energy consumption of the forwarder according to Athanassiadis (2000), who stated that in Sweden the average estimated fuel consumption of forwarders was $0.935 \mathrm{I} \mathrm{m}^{-3}$ (under bark) during transportation of roundwood. Ackerman et al. (2017) found that the fuel consumption was $0.38 \mathrm{I} \mathrm{m}^{-3}$ or $13.45 \mathrm{I} \mathrm{h}^{-1}$ when extracting timber assortments from pine stands in South Africa. Lijewski et al. (2017) calculated forwarder fuel consumption by measuring emissions of $\mathrm{CO}_{2}$ and stated average fuel consumption at $0.57 \mathrm{I} \mathrm{m}^{-3}$. The authors also performed an analysis of fuel consumption of each part of the working cycle and observed that the highest fuel consumption (as much as 53\%) was generated by timber loading and vehicle maneuvering, and the smallest fuel consumption was during transport. According to Kenney et al. (2014) average fuel consumption in forwarders was $11.09 \mathrm{I} \mathrm{h}^{-1}(2.93 \mathrm{GPH})$ in Alabama (USA), while Abbas et al. (2014) stated that in Michigan, it was a tad higher at $12.11 \mathrm{Ih}^{-1}$.

Nordfjell et al. (2003), based on the results obtained by comprehensive field investigation, provided an equation for the calculation of the fuel consumption of the 20- to 21-ton forwarder while extracting roundwood and pulpwood without bark in conditions of good soil bearing capacity (eqn. 1):

$$
Q=0.288+(0.00638 / V) \cdot L
$$

is the load volume $\left(\mathrm{m}^{3}\right)$, and $\mathrm{L}$ is the average extraction distance $(\mathrm{m})$.

Suvinen (2006) compared the fuel consumption of an unloaded and loaded forwarder with different equipment (tires only, chains on rear wheels and tracks on rear bogie axle with chains on rear wheels of front bogie axle) and concluded that chains on the wheels and half-tracks significantly increased fuel consumption in conditions of good soil bearing capacity and in such cases it is economically justified to remove them.

Löfroth \& Rådström (2006) pointed to a reduction of forwarder's fuel consumption during primary timber transport in Sweden, where fuel consumption decreased from $2.5 \mathrm{I} \mathrm{m}^{-3}$ to $1.7 \mathrm{I} \mathrm{m}^{-3}$ between 1985 and 2005. According to the authors, this reduction was attributed to the cooperation between machine manufacturers, machine users and researchers. As future guidelines for reducing fuel consumption authors highlighted: (i) the application of more efficient diesel engines; (ii) the increase in the efficiency of the hydraulic systems with efficiency below 60\%; (iii) the incorporation of the CTI (Central Tire Inflation) system; (iv) energy recovery from lowering individual hydraulic crane boom due to gravity; (v) optimization of export trail network; (vi) marking of logs in the forest with GPS devices; and (vii) further development and improvement of an electric-hybrid forwarder.

Beneficial effect of the CTI system on fuel consumption and soil damage was already given by Munro \& MacCulloch (2008) and Ghaffariyan (2017).

Forwarder with an electric-hybrid transmission, compared to the standard hydrostatic-mechanical transmission has a lower fuel consumption up from $20 \%$ to $50 \%$ and a lower mass because of a simpler transmission system without a bogie axle. Its mass is $9,500 \mathrm{~kg}$, while its carrying capacity is $12,000 \mathrm{~kg}$ (Löfroth et al. 2007, Spinelli 2011).

It is known that in the near future substantial reductions in greenhouse gas emissions from transportation will be required. This study aims to compare the fuel consumption in two different forwarder models during extraction of roundwood and energy wood in the lowland stands of pedunculate oak in order to assess the impact of changes in different vehicles, loads and stand conditions on transportation energy consumption.

\section{Materials and methods}

\section{Stand characteristics}

The study was conducted in the compartments $143 \mathrm{a}$ ( $45^{\circ} 03^{\prime} 52.2^{\prime \prime} \mathrm{N}, 18^{\circ} 53^{\prime} 35.4^{\prime \prime} \mathrm{E}$ ) and $64 \mathrm{f}\left(44^{\circ} 57^{\prime} 11.6^{\prime \prime} \mathrm{N}, 19^{\circ} 02^{\prime} 56.2^{\prime \prime} \mathrm{E}\right)$, Forest Administration Vinkovci, lowland part of Croatia. The research was carried out during seed and final cut in the stands of pedunculate oak and narrow-leafed ash. Age of the stand in the sub-compartment
$143 a$ was 134 years, and a total of 249 trees were marked for the seed cut comprising to the volume of $537 \mathrm{~m}^{3}$. Average length of the assortments was $3.71 \mathrm{~m}$ with average volume of $0.47 \mathrm{~m}^{3}$. Age of the stand in the sub-compartment $64 \mathrm{f}$ was 140 years, and a total of 203 trees were marked for the final cut comprising to the volume of $1221 \mathrm{~m}^{3}$. Average length of the assortments was $3.43 \mathrm{~m}$ with average volume of $0.80 \mathrm{~m}^{3}$. Terrain was flat with an altitude between 79-81 m. In the investigated departments, felling and processing were made with a chainsaw. Forest residues were transported by forwarders, which means that the transport of energy wood took place after the transportation of the roundwood. Felling and extracting were time-separated. The timber was processed by a buckto-quality method according to the current standards, while the crowns were cut as needed for easier loading and transportation of energy wood. During the extraction of roundwood by Valmet 840.2 forwarder, the ground was covered with a $10 \mathrm{~cm}$ thick snow cover that was melting on a daily basis. The snow has completely melted until the last day of the extraction of energy wood (measured soil cone index $-\mathrm{Cl}$ was $0.85 \mathrm{MPa}$ ). During the extraction of roundwood and energy wood by Valmet $860.4^{\circledR}$ forwarder, the ground was dry with good soil bearing capacity (measured soil cone index - $\mathrm{Cl}$ was 1.26 MPa).

\section{Machines and fuel consumption \\ measurement}

The objects of research were a 6-wheel Valmet $840.2^{\oplus}$ forwarder (Fig. 1a) and an 8wheel Valmet $860.4^{\oplus}$ forwarder (Fig. 1b). Their technical features are shown in Tab. 1. To measure fuel consumption for the Valmet 840.2 forwarder, a FFS $/ \mathrm{I}^{\circledast}$ differential flow meter device (EltraTec, Slovenia) was installed on the fuel supply line that supplies fuel from the fuel tank to the highpressure fuel pump on the propulsion engine. As the pump always provides more fuel than the engine consumes, a certain amount of fuel is still returned to the tank. To measure the exact amount of the used fuel, the return fuel also passes through the measuring device so a differential correction can be made. The advantage of this measuring device is a precise measurement of the fuel consumption.

For measuring fuel consumption of Valmet $860.4^{\circledast}$ forwarder a LLS $20160^{\circledR}$ fuel measuring probe (Omnicomm, Moscow, Russia) was used in the second part of the research. The measuring probe detects a sudden drop in fuel levels and uses a Fleet Management System (FMS) with wireless data transmission to the machine owner.

The FMS's role is to record specific parameters on the vehicle and wireless data transfer via GPRS or SMS through the monitoring centre to the end user. The end user has insight into vehicle parameters by internet connection using a computer or a mobile phone. The standard parameters 
that are monitored on virtually every vehicle are mainly the current position of the vehicle ( $x$ and $y$ coordinates), fuel consumption and engine rotation speed. The fundamental component of the FMS is a mobile unit that is mounted on the vehicle and at all times monitors its position via GPS device (navigation component), which is its integral part. For vehicle communication with the monitoring centre, the mobile unit also had a built-in GPRS modem that represents the communication component of the system.

The biggest advantage of the mobile unit is that it can be connected to different measuring transducers that can be used to monitor the operation of the vehicle. The measuring transducers that were connected to the mobile unit in this study were a flow meter device for measuring fuel consumption and a tachometer for measuring the speed of the propulsion engine. The mobile unit was also connected to forwarders' computer and to one of the solenoid valves of the hydraulic installation through which the hydraulic crane is operated.

\section{Data collection and analysis}

In the data obtained from the control centre system (FMS), containing the fuel consumption along with the coordinates of the forwarders' position, detection of hydraulic crane operation and the engine speed is shown in dependency of time. All recorded parameters were compared in the program package $\operatorname{ArcGIS}^{\circledast}$ ver. 10.1 (ESRI, Redlands, CA, USA) and fixed (transition) points were determined. Fixed points represent the shift between the individual stages of the working cycle. Each working cycle was divided into four basic stages: (i) driving unloaded; (ii) loading; (iii) driving loaded; and (iv) unloading. Based on the transition points, fuel consumption was calculated for each of the individual stage and finally for the total fuel consumption of each working cycle (I cycle $\left.{ }^{-1}\right)$.

With the help of the transition points and with calculation, a time duration of each stage of the working cycle was obtained, which provided data for the calculation of the total period of each working cycle and hourly fuel consumption $\left(\mathrm{I} \mathrm{h}^{-1}\right)$.

Using ArcGIS based on the recorded coordinates of the position of the forwarder, the length of the travelled distance was obtained, and the fuel consumption was expressed by consumed fuel per $100 \mathrm{~m}$ of travelled distance $\left(\mathrm{I} 100 \mathrm{~m}^{-1}\right)$.

During the extraction of the logs, the data of identification plates (containing tree species, volume, assortment type, etc.) of the assortments were gathered on the landing site. Identification plates were placed on the front of every log in the forest stand after processing and before extraction. Based on these numbers a gross volume (over bark) of each piece of roundwood in each working cycle of forwarders was obtained. The length of the logs was

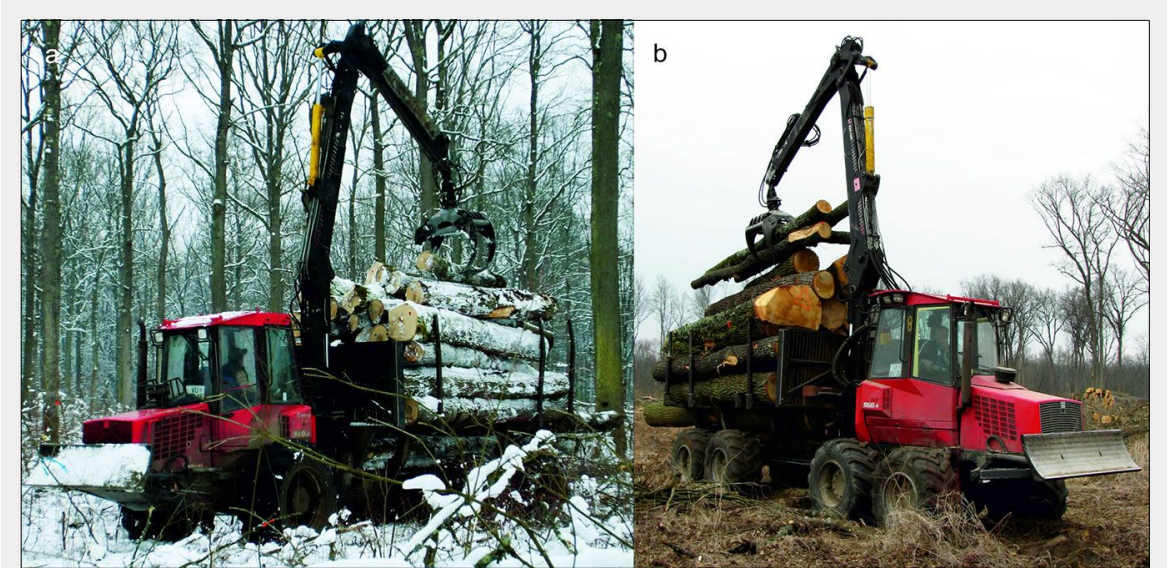

Fig. 1 - Forwarders (a) Valmet 840.2 and (b) Valmet 860.4 (photo: Z. Pandur).

measured with a measuring tape, and a calliper was used for measuring mid-diameter of each log. The fuel consumption in each working cycle of forwarders was related to the total gross volume of logs, and based on that fuel consumption per cubic meter of extracted timber $\left(\mathrm{I} \mathrm{m}^{-3}\right)$ was calculated.

On the landing site, a portable measuring platform described by Bosner et al. (2008) and Zorić et al. (2012) was installed for measuring axle load of forwarders. For each working cycle, the measuring platform was used during extraction of logs and energy wood. The mass of the load in each working cycle was obtained by measuring axle load of empty and full forwarders. With the ratio of consumed fuel to load mass in each working cycle, fuel consumption per ton of extracted timber (I $\left.t^{-1}\right)$ was obtained.

Finally it was decided that the most accurate way to express fuel consumption is the ratio of consumed fuel to travelled distance and the mass of the extracted timber $\left(\mathrm{t} \mathrm{t}^{-1} \mathrm{~km}^{-1}\right)$.

Tab. 1 - Main technical features of researched forwarders. $\left(^{*}\right)$ Declared: listed in the prospectus for the basic model; weighted: a real mass of researched forwarders with additional equipment (bigger/stronger hydraulic crane, front pushing board, etc.).

\begin{tabular}{lll}
\hline Feature & Valmet 840.2 & Valmet 860.4 \\
\hline Drive equation & $6 \times 6$ & $8 \times 8$ \\
\hline Mass $(\mathrm{kg})$ - declared/weighted * & $13,800 / 16,100$ & $16,060 / 18,750$ \\
\hline Load carrying capacity $(\mathrm{kg})$ & 11,000 & 14,000 \\
\hline Length $(\mathrm{mm})$ & 9,007 & 9,920 \\
\hline Width $(\mathrm{mm})$ & 2,640 & 2,760 \\
\hline Height $(\mathrm{mm})$ & 3,800 & 3,906 \\
\hline Ground clearance $(\mathrm{mm})$ & 680 & 680 \\
\hline Engine type & Valmet 620 DWRE & Sisu Diesel 66 CTA \\
\hline Power $(\mathrm{kW})$ at $2,200 \mathrm{rpm}$ & 124 & 145 \\
\hline Euro emission standard & Euro 2 & Euro $3 \mathrm{~A}$ \\
\hline Torque $(\mathrm{Nm})$ & $670 \mathrm{Nm}$ at $1,400 \mathrm{rpm}$ & $800 \mathrm{Nm}$ at $1,500 \mathrm{rpm}$ \\
\hline Transmission & Hydrostatic-mechanical & Hydrostatic-mechanical \\
\hline Length of bunk area $(\mathrm{mm})$ & 4,200 & 4,400 \\
\hline Hydraulic crane type & CRF 7 & CRF 14 \\
\hline Maximum crane reach $(\mathrm{m})$ & 9.1 & 7.5 \\
\hline Tires: front & $600 / 65 \times 34$ & $600 / 55 \times 26.5$ \\
\hline Tires: rear & $600 / 55 \times 26.5$ & $600 / 55 \times 26.5$ \\
\hline
\end{tabular}

Statistical analysis was carried out using the software package STATISTICA ${ }^{\oplus}$ ver. 8 (StatSoft Inc., Tulsa, OK, USA). To examine significant differences between two independent data sets, Student's t-test was used with a level of $5 \%$ significance $(\alpha=$ $0.05)$ and in the study of stochastic dependence between correlated variables regression analysis was used. The selection of the equalisation curve was carried out by the coefficient of correlation ( $R$ ), $t$-variable ( $t$ Stat), the probability value $(\mathrm{p}<0.05)$ and regression coefficients.

\section{Results and discussion}

\section{Valmet 840.2 fuel consumption}

In the case of fuel consumption per working cycle, higher consumption was observed during extraction of roundwood $\left(15.61 \mathrm{I}\right.$ cycle $\left.{ }^{-1}\right)$ than while extracting energy wood ( $14.81 \mid$ cycle $\left.^{-1}\right)$, but according to the $t$-test, there was no difference statistically significant in consumption per working cycle between those two variants (Tab. 2). 
Tab. 2 - Fuel consumption of Valmet 840.2 and Valmet 860.4 forwarders. Values in the same row (for each forwarder separately) marked with the same letter do not represent significant difference according to $t$-test $(p<0.05)$.

\begin{tabular}{|c|c|c|c|c|c|}
\hline \multirow{2}{*}{ Characteristic } & \multirow{2}{*}{ Units } & \multicolumn{2}{|c|}{ Valmet $\mathbf{8 4 0 . 2}$} & \multicolumn{2}{|l|}{ Valmet $\mathbf{8 6 0 . 4}$} \\
\hline & & Roundwood & Energy wood & Roundwood & Energy wood \\
\hline \multirow{6}{*}{$\begin{array}{l}\text { Fuel consumption } \\
-Q\end{array}$} & l cycle $^{-1}$ & $15.61^{\mathrm{a}}$ & $14.81^{\mathrm{a}}$ & $6.22^{\mathrm{a}}$ & $7.09^{\mathrm{a}}$ \\
\hline & $\mathrm{l} 100 \mathrm{~m}^{-1}$ & $0.69^{a}$ & $0.66^{\mathrm{a}}$ & $0.65^{\mathrm{a}}$ & $0.64^{\mathrm{a}}$ \\
\hline & $1 h^{-1}$ & $17.36^{\mathrm{a}}$ & $15.17^{b}$ & $12.13^{\mathrm{a}}$ & $12.48^{\mathrm{a}}$ \\
\hline & $1 t^{-1}$ & $1.29^{\mathrm{a}}$ & $1.74^{\mathrm{b}}$ & $0.44^{\mathrm{a}}$ & $0.9^{\mathrm{b}}$ \\
\hline & $1 \mathrm{~m}^{-3}$ & 1.18 & - & 0.42 & - \\
\hline & $\mathrm{lt}^{-1} \mathrm{~km}^{-1}$ & $0.56^{a}$ & $0.78^{\mathrm{b}}$ & $0.45^{\mathrm{a}}$ & $0.83^{\mathrm{b}}$ \\
\hline Working cycles & $\mathrm{n}$ & 28 & 24 & 57 & 48 \\
\hline Load mass & $\mathrm{kg}$ & $12,317^{\mathrm{a}}$ & $8,468^{b}$ & $14,689^{a}$ & $7,996^{\mathrm{b}}$ \\
\hline Load volume & $\mathrm{m}^{3}$ & 13.37 & - & 15.08 & - \\
\hline $\begin{array}{l}\text { Total extraction } \\
\text { distance }\end{array}$ & $\mathrm{m}$ & $2,272^{\mathrm{a}}$ & $2,235^{\mathrm{a}}$ & $1,000^{\mathrm{a}}$ & $1,235^{\mathrm{b}}$ \\
\hline
\end{tabular}
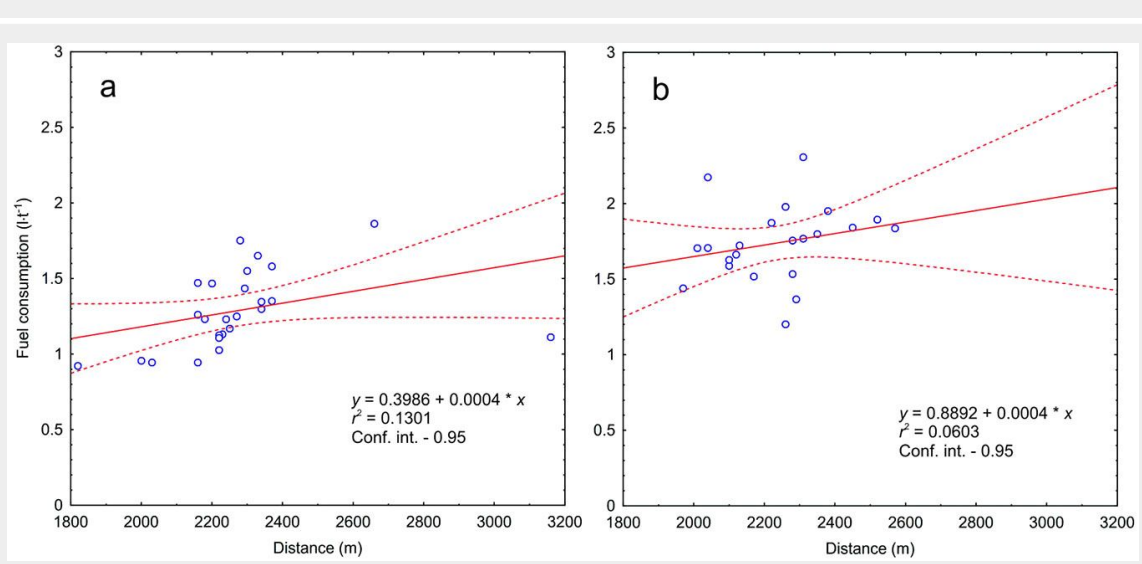

Fig. 2 - The ratio of fuel consumption and total travelled distance with the Valmet 840.2 forwarder (Slavir, 143a). (a) Roundwood; (b) energy wood.

Regarding fuel consumption per distance of $100 \mathrm{~m}$, there was also no significant difference between the consumption during extraction of roundwood and energy wood. However, fuel consumption was higher during extraction of roundwood $\left(0.69 \mathrm{I}_{\left.100 \mathrm{~m}^{-1}\right)}\right.$ in comparison with extraction of energy wood (0.66 I $\left.100 \mathrm{~m}^{-1}\right)$. Also when calculated per hour, fuel consumption was higher while extracting roundwood $\left(17.36 \mathrm{I} \mathrm{h}^{-1}\right)$ rather than energy wood $\left(15.17 \mid \mathrm{h}^{-1}\right)$, differences were also statistically significant.

The reason for the higher fuel consumption during extracting of roundwood can be attributed to the higher mass loadable due to a higher bulk density of the load, which averaged in $12,317 \mathrm{~kg}$ and which is statistically different from the average mass of energy wood $(8,468 \mathrm{~kg})$. Though, the extraction differences in distances for roundwood $(2,272 \mathrm{~m})$ and energy wood $(2,335 \mathrm{~m})$ were not statistically significant. The fuel consumption per metric tons of transported load was higher when extracting energy wood $\left(1.74 \mid \mathrm{t}^{-1}\right)$ and significantly differed from fuel consumption when extracting roundwood $\left(1.29 \mid \mathrm{t}^{-1}\right)$. The reason for the higher fuel consumption during extraction of energy wood expressed in this way was the lower average mass of energy wood load compared to loads of roundwood.

The fuel consumption per gross volume of the load when extracting roundwood was $1.18 \mathrm{I} \mathrm{m}^{-3}$. According to the fuel consumption expressed in $\mathrm{I} \mathrm{t}^{-1} \mathrm{~km}^{-1}$, the value of $0.56 \mathrm{I} \mathrm{t}^{-1} \mathrm{~km}^{-1}$ while extracting roundwood was achieved, while the fuel consumption during extraction of energy wood was 0.78 $\mathrm{I} \mathrm{t}^{-1} \mathrm{~km}^{-1}$. The difference between these two values was statistically significant.

The increasing trend is the same while extracting both roundwood and energy wood, but the amount of fuel consumption is higher when it comes to energy wood extraction because of the reduced load mass (Fig. 2). No dependence between fuel consumption and extraction distance was obtained.

The biggest share in forwarders' fuel consumption was while driving unloaded (Tab. 3). In both stages of the working cycle, time duration was the same (driving unloaded: $16.8 \%$ and $17.8 \%$ for roundwood and energy wood, respectively; driving loaded: $19.5 \%$ and $20.9 \%$ for roundwood and energy wood, respectively). Shares of fuel consumption in these stages were similar as well as the shares of travelled distance, together comprising over $80 \%$ of the total travelled distance in an average working cycle. In this case, the travelled distance had a greater impact on the total fuel consumption than the time duration of the working cycle stages.

In the case of a loading stage, the share of fuel consumption while loading energy wood $(27.2 \%)$ was higher than while loading roundwood $(17.2 \%)$. While loading energy wood, timeshare was also higher (42.3\%) compared to time used for loading roundwood (29\%). The reason for the higher fuel consumption and the amount of time during loading energy wood was the higher number of solenoid valve engagements for the displacement of the hydraulic crane (163) and the higher workload of the hydraulic crane compared to loading roundwood where on average 99 engagements were detected (the crane was controlled via solenoid valve and through its activity the activity of the crane was detected). The reason for the increased number of hydraulic crane engagements during unloading roundwood was of organisational nature, i.e., logs were subsequently measured at the landing site to confirm the measures previously taken in the stand. Thus, it can be assumed that the number of hydraulic crane engagements (163) was

Tab. 3 - Shares of fuel consumption by stages of the working cycle of the Valmet 840.2 forwarder (Slavir, 143a).

\begin{tabular}{lcccccrrrr}
\hline \multirow{2}{*}{ Stage } & \multicolumn{2}{c}{ Time share (\%) } & \multicolumn{2}{c}{$\begin{array}{c}\text { Share of fuel } \\
\text { consumption (\%) }\end{array}$} & \multicolumn{2}{c}{$\begin{array}{c}\text { Share of travelled } \\
\text { distance (\%) }\end{array}$} & \multicolumn{2}{c}{$\begin{array}{c}\text { Hydraulic crane } \\
\text { engagement }(N)\end{array}$} \\
\cline { 2 - 9 } & Roundwood & $\begin{array}{c}\text { Energy } \\
\text { wood }\end{array}$ & Roundwood & $\begin{array}{c}\text { Energy } \\
\text { wood }\end{array}$ & Roundwood & $\begin{array}{c}\text { Energy } \\
\text { wood }\end{array}$ & $\begin{array}{c}\text { Roundwood } \\
\text { Roundwy } \\
\text { wood }\end{array}$ \\
\hline Driving unloaded & 16.8 & 17.8 & 30.2 & 32.3 & 41.2 & 42.5 & - & - \\
Loading & 29.0 & 42.3 & 17.2 & 27.2 & 7.7 & 9.8 & 99 & 163 \\
\hline Driving loaded & 19.5 & 20.9 & 28.2 & 28.2 & 42.5 & 44.4 & - & - \\
\hline Unloading & 34.7 & 19.0 & 24.4 & 12.3 & 8.6 & 3.4 & 163 & 78 \\
\hline
\end{tabular}


Tab. 4 - Shares of fuel consumption by stages of the working cycle of the Valmet 860.4 forwarder (Debrinja, 64f).

\begin{tabular}{lccccrr}
\hline \multirow{2}{*}{ Stage } & \multicolumn{2}{c}{$\begin{array}{c}\text { Time share } \\
\text { (\%) }\end{array}$} & \multicolumn{2}{c}{$\begin{array}{c}\text { Share of fuel } \\
\text { consumption (\%) }\end{array}$} & \multicolumn{2}{c}{$\begin{array}{c}\text { Share of travelled } \\
\text { distance (\%) }\end{array}$} \\
\cline { 2 - 7 } & Roundwood & Energy wood & Roundwood & Energy wood & Roundwood & Energy wood \\
\hline Driving unloaded & 19.2 & 14.7 & 13.8 & 18.3 & 36.2 & 37.2 \\
\hline Loading & 40.6 & 46.5 & 33.2 & 43.0 & 14.5 & 9.1 \\
\hline Driving loaded & 22.3 & 22.0 & 31.8 & 22.2 & 41.3 & 51.2 \\
\hline Unloading & 17.9 & 16.8 & 21.2 & 16.5 & 8.0 & 2.4 \\
\hline
\end{tabular}

three times higher than it would be in noramount to around 55 engagements. In that case, the workload of the hydraulic crane would be lower both during loading and unloading of roundwood compared to loading and unloading of energy wood (Tab. 4).

\section{Valmet 860.4 fuel consumption}

Higher fuel consumption per working cycle was recorded during extraction of energy wood (7.09 I cycle-1) compared to extraction of roundwood (6.22 I cycle $^{-1}-$ Tab. 2). According to $t$-test between these two fuel consumptions, the difference was no statistically significant. Higher fuel consumption was determined due to the differences in landing sites' position, where landing site of energy wood was more distant. Regarding fuel consumption expressed per travelled distance $\left(1100 \mathrm{~m}^{-1}\right)$ and hourly fuel consumption $\left(\mathrm{I} \mathrm{h}^{-1}\right)$, there was no statistically significant difference.

Fuel consumption expressed in tons of extracted timber was lower during roundwood extraction ( $0.44 \mathrm{I} \mathrm{t}^{-1}$ ) compared to fuel consumption during energy wood extraction $\left(0.9 \mid t^{-1}\right)$ with a statistically significant difference. The reason for this is almost $50 \%$ lower mass of average load of energy wood $(7,996 \mathrm{~kg})$ compared to the average mass of roundwood load (14,689 $\mathrm{kg})$.

A similar situation was also observed in fuel consumption expressed in $\mathrm{I} \mathrm{t}^{-1} \mathrm{~km}^{-1}$, where the fuel consumption while extracting roundwood was almost halved ( 0.45 I $\mathrm{t}^{-1} \mathrm{~km}^{-1}$ ) compared to the fuel consumption during energy wood extraction $\left(0.83 \mathrm{I} \mathrm{t}^{-1}\right.$ $\mathrm{km}^{-1}$ ) with a statistically significant difference.

The largest share of fuel consumption refers to the loading stage of both loads together with the highest timeshares (Tab. 2). A higher percentage of fuel consumption is observed while loading energy wood (43\%) compared to loading of round$\operatorname{wood}(33.2 \%)$.

The share of travelled distance (driving unloaded, driving loaded) during extraction of energy wood differed significantly from the share of travelled distance during extraction of roundwood. The reason for this was the further landing site position for energy wood. It is interesting to note that despite a bigger share of travelled distances while extracting energy wood (drivmal working circumstances, which would ing loaded), the percentage of fuel consumption was lower compared to driving loaded during extracting roundwood, which indicates that fuel consumption is directly affected by load mass.

Significant differences existed in the share of fuel consumption while loading and unloading. A higher share of fuel consumption was recorded while loading energy wood. This was due the large and curved branches of old oak crowns that were difficult to load in order to maximise the yield of the load carrying capacity. Contrasting results were obtained while unloading. In case of unloading the roundwood, the forwarder had to maneuver in the landing site to separate the logs depending on quality classes (felling and processing was made using buck-to-quality method), while the unloading of the energy wood was carried without additional maneuvering of the vehicle. The cause of higher fuel consumption may also be due to increased fuel fluctuations, whose change was recorded by the measuring probe during unloading/loading of larger logs and swinging of the entire forwarder.

When comparing both load types, the lowest fuel consumption was measured at the unloading stage (16.5\%) and was slightly higher while driving unloaded (18.3\%) and higher while driving loaded (22.2\%). Fuel consumption shares in this load type followed the ratio of timeshares of working cycle stages.

When extracting round wood, the use of fuel per $\mathrm{m}^{3}$ was generally lower in comparison with energy wood (Fig. 3), however
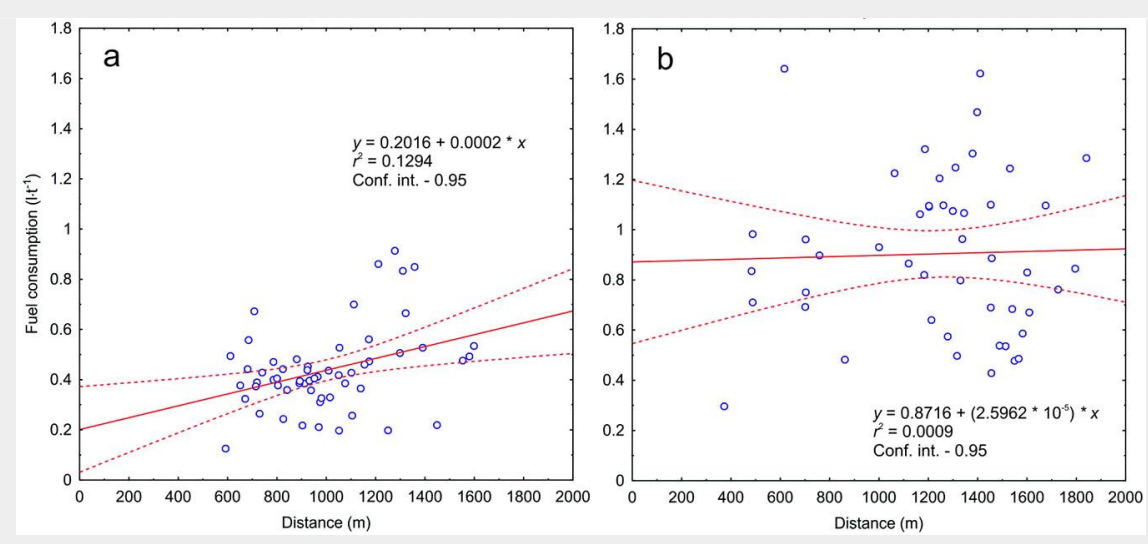

Fig. 3 - The ratio of fuel consumption and total travelled distance with the Valmet 860.4 forwarder (Debrinja, 64f). (a) Roundwood; (b) energy wood. distance.

\section{Comparison of fuel consumption} spectively. crease of slip, etc.). the growth dynamic was bigger in round wood. The change (increase) of fuel consumption when extracting energy wood was nearly not observed (Fig. 3). It can be concluded that there is no dependence of unit fuel consumption on the extraction

Higher fuel consumption was measured for Valmet 840.2 forwarder in all expressed fuel consumption ratios (Tab. 2). Indeed, the reason for more than double the consumption per working cycle is the higher total travelled distance, which was $2,272 \mathrm{~m}$ while extracting roundwood and 2,235 m for energy wood extraction. During extraction of roundwood and energy wood Valmet 860.4 forwarder had an average total travelled distance of 1,000 and $1,235 \mathrm{~m}$, re-

Regarding fuel consumption expressed per total travelled distance, fuel consumption was slightly higher for Valmet 840.2 forwarder ( 0.69 and $0.66 \mathrm{I} 100 \mathrm{~m}^{-1}$ for roundwood and energy wood, respectively) than it was for Valmet 860.4 for-

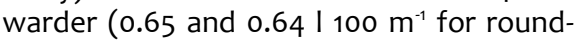
wood and energy wood, respectively). The reason for that is that Valmet 840.2 forwarder was for the majority of travelled distance (1550 m of total $2272 \mathrm{~m}$ and 2235 $\mathrm{m}$ ) driving in bad conditions (mud, melting of the snow, low soil bearing capacity, in-

Nordfjell et al. (2003) stated that fuel consumption of forwarder in Scots pine stand during final cut and in good stand condi-

iForest 12: 125-131 

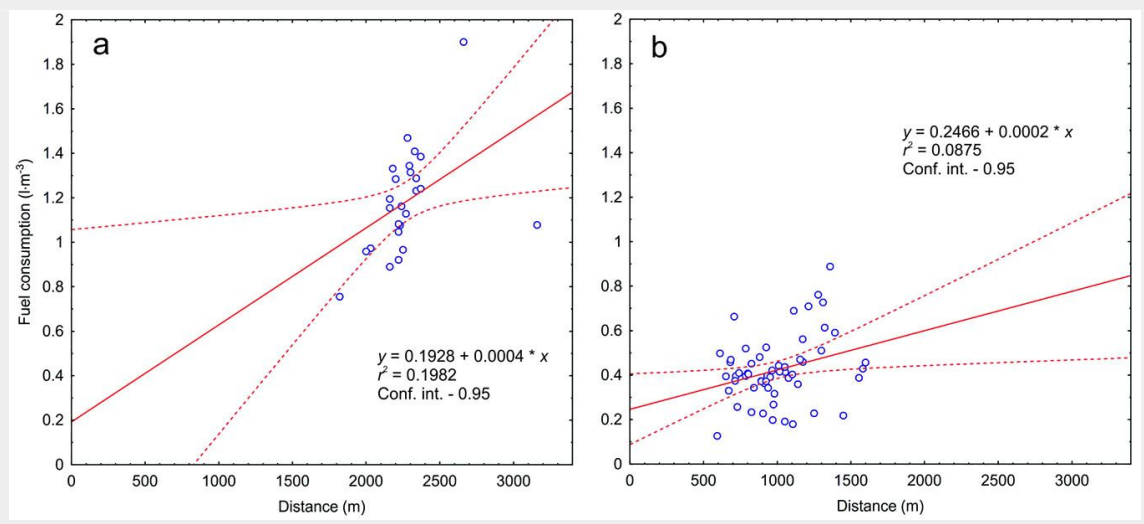

Fig. 4 - Dependence of fuel consumption per gross volume of roundwood on the total travelled distances. (a) Valmet 840.2 (Slavir, 143a); (b) Valmet 860.4 (Debrinja, 64f).

tions regarding soil bearing capacity was between 0.23 and $0.381100 \mathrm{~m}^{-1}$.

Concerning hourly fuel consumption, Valmet 840.2 forwarder had a higher consumption on both types of load (17.36 and $15.17 \mathrm{I} \mathrm{h}^{-1}$ for roundwood and energy wood, respectively) compared to the Valmet 860.4 forwarder (12.13 and $12.48 \mathrm{I}^{\mathrm{h}} \mathrm{h}^{-1}$, respectively). Many authors (Nordfjell et al. 2003, Rieppo \& Orn 2003, Holzleitner et al. 2010, Kenney et al. 2014, Abbas et al. 2014, Ackerman et al. 2017) summarized that fuel consumption varies between 8.3 to $15.7 \mathrm{I} \mathrm{h}^{-1}$ depending on the vehicle size and stand conditions.

Fuel consumption per ton of transported timber was almost three times higher for Valmet 840.2 forwarder compared to the Valmet 860.4 forwarder (1.29 vs. $0.44 \mathrm{I} \mathrm{t}^{-1}$, respectively) while extracting roundwood, or nearly twice as high while extracting energy wood (1.74 vs. $0.9 \mathrm{I} \mathrm{t}^{-1}$ for Valmet 840.2 and Valmet 860.4 , respectively). Payload of the Valmet 840.2 forwarder is smaller which led to a higher fuel consumption per mass of transported timber. Also, conditions in the stand (higher distances, mud, low soil bearing capacity, wheel slip) all contributed to higher fuel consumption of the Valmet 840.2 forwarder.

Fuel consumption expressed per gross volume of roundwood was almost three times higher for Valmet 840.2 compared to the Valmet 860.4 forwarder ( 1.18 vs. 0.42 I $\mathrm{m}^{-3}$, respectively). Previous studies (Athanassiadis 2000, Nordfjell et al. 2003, Ackerman et al. 2017, Lijewski et al. 2017) reported a fuel consumption of forwarders varying between 0.38 and $0.94 \mathrm{I} \mathrm{m}^{-3}$.

Tab. 5 - Total fuel consumption measured by measuring probe on the Valmet 860.4 forwarder per stages of the working cycle and on a daily level.

\begin{tabular}{lcc}
\hline Fuel consumption & Roundwood & Energy wood \\
\hline Working cycles $(\mathrm{n})$ & 57 & 48 \\
\hline By stages of working cycle $(\mathrm{l})$ & 354.6 & 340.3 \\
\hline By day (l) & 416.6 & 372.4 \\
\hline Difference (\%) & 14.88 & 8.62 \\
\hline
\end{tabular}

Fuel consumption expressed in $\mathrm{I} \mathrm{t}^{-1} \mathrm{~km}^{-1}$ during roundwood extraction was higher for Valmet $840.2\left(0.56 \mathrm{I} \mathrm{t}^{-1} \mathrm{~km}^{-1}\right)$ compared to the Valmet 860.4 forwarder $\left(0.45 \mathrm{I} \mathrm{t}^{-1}\right.$ $\mathrm{km}^{-1}$ ), while the opposite holds for the extraction of energy wood, where Valmet 840.2 forwarder had lower fuel consumption than Valmet 860.4 ( 0.78 vs. $0.83 \mathrm{I} \mathrm{t}^{-1}$ $\mathrm{km}^{-1}$, respectively). The fuel consumption expressed in this way is the most accurate fuel consumption indicator because it allows a realistic comparison of different types of machines with different loads ( $t$, $\mathrm{m}^{3}$ ) at different extraction distances.

As expected, both forwarders had higher fuel consumption with higher travelling distances, and the higher increase in consumption was for Valmet 840.2 forwarder (Fig. 4). The reason for the higher fuel consumption of the Valmet 840.2 forwarder were poor stand conditions (melting of snow), which has led to increased wheel slipping (15.81\%, measured in the stand) and a significant share of the travelled distance on the wet forest trails $(74 \%$ and $75.6 \%$ of the total travelled distance occurred on the forest trails while extracting roundwood and energy wood, respectively).

The extraction conditions at the study site where the Valmet 860.4 forwarder was tested (Debrinja, 64f) were more favorable, as the ground was dry and the wheel slipping was below $6 \%$. Moreover, this subcompartment is located directly beside the forest road along which were the landing sites for roundwood and energy wood. According to the fuel consumption expressed in $\mathrm{I} \mathrm{t}^{-1} \mathrm{~km}^{-1}$, the fuel consumption of the Valdifferential flow meter is its sensitivity to

impurities that may appear in the fuel (Pan-
dur et al. 2009). The installation of newer
engine types with built-in sensors may re-
sult in a drop in pressure in the fuel supply
system and in difficulties in the operation
of the propulsion engine. For fuel con-
sumption measurements, probes can also

impurities that may appear in the fuel (Pan-
dur et al. 2009). The installation of newer
sult in a drop in pressure in the fuel supply
system and in difficulties in the operation
of the propulsion engine. For fuel con-
sumption measurements, probes can also

impurities that may appear in the fuel (Pan-
dur et al. 2009). The installation of newer
engine types with built-in sensors may re-
sult in a drop in pressure in the fuel supply
system and in difficulties in the operation
of the propulsion engine. For fuel con-
sumption measurements, probes can also

impurities that may appear in the fuel (Pan-
dur et al. 2009). The installation of newer
engine types with built-in sensors may re-
sult in a drop in pressure in the fuel supply
system and in difficulties in the operation
of the propulsion engine. For fuel con-
sumption measurements, probes can also

impurities that may appear in the fuel (Pan-
dur et al. 2009). The installation of newer
engine types with built-in sensors may re-
sult in a drop in pressure in the fuel supply
system and in difficulties in the operation
of the propulsion engine. For fuel con-
sumption measurements, probes can also

impurities that may appear in the fuel (Pan-
dur et al. 2009). The installation of newer
sult in a drop in pressure in the fuel supply
system and in difficulties in the operation
of the propulsion engine. For fuel con-
sumption measurements, probes can also

impurities that may appear in the fuel (Pan-
dur et al. 2009). The installation of newer
engine types with built-in sensors may re-
sult in a drop in pressure in the fuel supply
system and in difficulties in the operation
of the propulsion engine. For fuel con-
sumption measurements, probes can also

met 860.4 forwarder while extracting energy wood was slightly higher compared to the Valmet 840.2 forwarder ( 0.83 vs. 0.78 I $\left.\mathrm{t}^{-1} \mathrm{~km}^{-1}\right)$. The reason for this was about 600 $\mathrm{kg}$ lower average load mass of energy wood transported by the Valmet 860.4 forarder.

The parameter that indicates the fuel consumption per cycle stage is based on the sum of the fuel consumption per each cycle stage, and the parameter showing the fuel consumption per day was obtained based on the fuel level difference at the end and the beginning of the working day, taking into account the refueling during the day (Tab. 5). According to this parameter, the expressed fuel consumption was more accurate than the fuel consumption obtained by the sum of the stages of the working cycle because at the beginning and the end of the working day the forwarder is idle, and there is no fluctuation of the fuel level in the tank caused by the the hydraulic crane. Fuel consumption per day was higher than that obtained by the sum of the stages of the working cycle (Tab. 5). This difference ranges from $8.62 \%$ for energy wood extraction and up to $14.88 \%$ for roundwood extractions. The diference is in connection to the number of cycles, as the number of cycles was higher some versions of timber extraction, and higher deviation in the fuel consumption measurements. Further causes of higher fuctuations in the fuel level and hence more substantial errors in the fuel level measurements are the operations of the hydraulic crane while loading and unloading larger logs and ground obstacles, such According

According to the expression 1 quoted by ordfjell et al. (2003), based on the volume of the load in $\mathrm{m}^{3}$ and the average extracon distance, the calculated fuel consumpon the Valmet 860.4 forwarder while xtracting roundwood in the sub-compartment $64 \mathrm{f}\left(0.49 \mathrm{I} \mathrm{m}^{-3}\right)$ was approximately equal to the measured fuel consumption $\left(0.42 \mathrm{I} \mathrm{m}^{-3}\right)$, while for the Valmet 840.2 forwarder the calculated fuel consumption was $0.77 \mathrm{I} \mathrm{m}^{-3}$ and measured fuel consump cant deviation of the Valmet 840.2 forwarder is due to the greater average extraction distances $(1,136 \mathrm{~m})$, while Nordfjell et al. (2003) conclude that the expression s suitable for a medium distance of about $400 \mathrm{~m}$. The average extraction distance of Valmet 860.4 forwarder was $500 \mathrm{~m}$, so the lculated consumption is more similar to e measured consumption. iForest 12: 125-131 
be installed in the fuel tank of the vehicle. The main disadvantage of the measuring probe is a lower precision than the differential fuel consumption device. Its advantage is its insensitivity to fuel impurities, while its main drawback is the insufficient precision, especially when working on uneven terrain, where the level of fuel in the tank is always perturbed.

\section{Conclusions}

The higher fuel consumption of the Valmet 840.2 forwarder reflects the worse working conditions during the test. Both forwarders had higher fuel consumption (expressed in $\mathrm{I} \mathrm{t}^{-1} \mathrm{~km}^{-1}$ ) when energy wood was extracted, because of the lower mass of energy wood compared to the mass of roundwood in the individual load of forwarders.

The increased hourly fuel consumption of the Valmet 840.2 forwarder can be partly due to the older generation engine (Valmet 620 DWRE), that meets the Euro 2 exhaust emission standards, and the older fuel injection system used by the line pump. The Valmet 860.4 forwarder is equipped with a newer generation propulsion engine (Sisu 66 (TA) that meets Euro 3 exhaust emission standards, and with a modern $C R$ (Common Rail) fuel injection system, which is considered more energy-efficient.

The fuel consumption measuring probe is not suitable for scientific research due to the large influence of external factors on the fuel level in the tank. In future studies, a flowmeter should be developed, or the fuel delivery system should be upgraded. The upgrading would consist mainly of installing an additional pump to prevent a fuel supply pressure drop due to the installation of a flowmeter less sensitive to external influences, such as those affecting fuel level measurements with a measuring probe. However, the flowmeter is sensitive to impurities in the fuel that prevent the normal flow. By installing an additional filter, this problem can be solved. The additional filter also has a positive effect on the pressure drop in the fuel supply system which triggers an alarm, warning about the occurrence of engine problems.

The solution is the purchase of a forwarder with a factory-fitted flowmeter for measuring the fuel consumption, for which the manufacturer guarantees precision and unobstructed operation during the service life of the vehicle.

\section{References}

Abbas D, Handler R, Hartsough B, Dykstra D, Lautala P, Hembroff L (2014). A survey analysis of forest harvesting and transportation operations in Michigan. Croatian Journal of Forest Engineering 35 (2): 179-192. [online] URL: http:// hrcak.srce.hr/127001?lang=en

Ackerman P, Williams C, Ackerman S, Nati C
(2017). Diesel consumption and carbon balance in South African pine clear-felling CTL Operations: a preliminary case study. Croatian Journal of Forest Engineering 38 (1): 65-72. [online] URL: http://hrcak.srce.hr/174451?lang=en

Athanassiadis D (2000). Energy consumption and exhaust emissions in mechanised timber harvesting operations in Sweden. Science of the Total Environment 255 (1-3): 137-145. - doi: 10.1016/S0048-9697(00)00463-0

Bosner A, Nikolić S, Pandur Z, Benić D (2008). Razvoj i umjeravanje prijenosnoga sustava za mjerenje osovinskih opterećenja vozila - mjerenja na forvarderu [Development and calibration of mobile measuring system of vehicle axle mass - Measurements on forwarder]. Nova mehanizacija šumarstva 29 (1): 1-15. [in Croatian]

Đuka A, Vusić D, Horvat D, Sušnjar M, Pandur Z, Papa I (2017). LCA studies in forestry - Stagnation or progress? Croatian Journal of Forest Engineering 38 (2): 311-326.

Ghaffariyan MR (2017). Impacts of central tire inflation system application on forest transportation - review. Journal of Forest Science 63 (4): 153-160. - doi: 10.17221/111/2016-JFS

Holzleitner F, Stampfer K, Ghaffariyan MR, Visser $R$ (2010). Economic benefits of long term forestry machine data capture: Austrian Federal Forest case study. In: Proceedings of the meeting "FORMEC 2010, Forest Engineering: Meeting the Needs of the Society and the Environment". Padova (Italy) 11-14 July 2010, pp. 1-8. [online] URL: http://www.researchgate.net/ publication/261988181

Kenney J, Gallagher T, Smidt M, Mitchell D, MCDonald (2014). Factors that affect fuel consumption in logging systems. In: Proceedings of the " $37^{\text {th }}$ Council on Forest Engineering Annual Meeting". Moline (IL, USA), 23 June 2014. COFE, Morgantown, WV, USA, pp. 6.[online] URL: http://www.fs.usda.gov/treesearch/pubs/ 48173

Lijewski P, Merkisz J, Fuć P, Ziólkowski A, Rymaniak L, Kusiak W (2017). Fuel consumption and exhaust emissions in the process of mechanized timber extraction and transport. European Journal of Forest Research 136 (1): 153160. - doi: 10.1007/s10342-016-1015-2

Löfroth C, Rådström L (2006). Fuel consumption in forestry continues to fall. Jan Fryk, Uppsala, Sweden, pp. 4.

Löfroth C, Jönsson P, Nordén B, Hofsten $\mathrm{H}$ (2007). Hybrid forwarder achieves considerable reduction in fuel consumption. Jan Fryk, Uppsala, Sweden, pp. 4.

Maesano M, Picchio R, Lo Monaco A, Neri F, Lasserre B, Marchetti M (2013). Productivity and energy consumption in logging operation in a Cameroonian tropical forest. Ecological Engineering 57: 149-153. - doi: 10.1016/j.ecoleng.2013. 04.013

Manner J, Nordfjell T, Lindroos O (2016). Automatic load level follow-up of forwarders' fuel and time consumption, International Journal of Forest Engineering 27 (3): 151-160. - doi: 10.108 o/14942119.2016.1231484

Martinić I, Tomanić S, Vondra V, Zovak T, Brekalo
Z (1992). Učinkovitost traktorskih ekipaža pri izvoženju oblovine [Efficiency of forest tractor assemblies during extracting logs]. Mehanizacija šumarstva 17 (1-2), 15-21. [in Croatian]

Munro R, MacCulloch F (2008). Tyre pressure control on timber haulage vehicles. Some observations on trial in Highland, Scotland. Roadex III Publications, Luleå, Sweden, pp. 75. [online] URL: https://www.roadex.org/wp-content/ uploads/2014/01/TPCS-Trial-RIII.pdf

Nordfjell T, Athanassiadis D, Talbot B (2003). Fuel consumption in forwarders. International Journal of Forest Engineering 14 (2): 11-20. - doi: 10.1080/14942119.2003.10702474

Pandur Z, Horvat D, Šušnjar M, Šarac Z (2009). Može li se komercijalni Fleet Management Sustav koristiti u praćenju rada i istraživanjima forvardera [Can a commercial fleet management system be used for research and survey of forwarder]? Nova mehanizacija šumarstva 30 (1): 11-17. [in Croatian]

Potočnik I (1989). Potrošnja goriva kamiona Magirus pri prijevozu drva [Fuel consumption of truck magirus during wood transporting]. Mehanizacija šumarstva 14 (7-8), 145-156. [in Croatian]

Rebula E (1989). Potrošnja goriva pri privlačenju drva s traktorima IMT 560 i IMT 567 [Fuel consumption of tractors IMT 560 and IMT 567 during wood extracting]. Mehanizacija šumarstva 14 (7-8), 151-155. [in Croatian]

Rieppo K, Orn J (2003). Measuring the fuel consumption of forest machines. Metsäteho Report 148, Helsinki, Finland, pp. 4.

Spinelli R (2011). Supply of wood biomass for energy purpose: global trends and perspectives. FederUnacoma, Rome, Italy, pp. 16. [online] URL: http://www.clubofbologna.org/ew/docum ents/Spinelli_KNR.pdf

Sever S, Horvat D, Golja V, Risović S (1989). Neki rezultati istraživanja potrošnje goriva na radovima proreda sastojina [Some research results of fuel consumption during thinning]. Mehanizacija šumarstva 14 (3-4): 49-54. [in Croatian] Sever S, Horvat D (1989). Prilog proučavanja potrošnje goriva pri prijevozu drva kamionskim kompozicijama [Fuel consumption study of forest truck assemblies]. Mehanizacija šumarstva 14 (7-8): 157-162. [in Croatian]

Suvinen A (2006). Economic comparison of the use of tyres, wheel chains and bogie tracks for timber extraction. Croatian Journal of Forest Engineering 27 (2): 81-102.

Vusić D, Šušnjar M, Marchi E, Spina R, Zečić Z, Picchio R (2013). Skidding operations in thinning and shelterwood cut of mixed stands Work productivity, energy inputs and emissions. Ecological Engineering 61: 216-223. - doi: 10.1016/j.ecoleng.2013.09.052

Zorić M, Horvat D, Pandur Z, Nikolić S (2012). Umjeravanje prijenosne mjerne platforme za mjerenje osovinskoga opterećenja vozila [Calibration of portable measuring platform for vehicle axle load measurement]. Nova mehanizacija 33 (1): 45-52. [in Croatian] 